\title{
Study of Some Phytochemicals in Talinium Triangulare Leaves
}

\author{
Don-lawson Chioma and Okah Reminus \\ Department of Science Laboratory Technology \\ School of Science and Technology, Port Harcourt Polytechnic, Rumuola. Port Harcourt. \\ * E-mail of the corresponding author: ogweru12345@gmail.com
}

\begin{abstract}
The phytochemical analysis of moringa leaves (wet and dry) using standard procedures shows it contains (\%) saponin $1.10 \%$, flavonoid $1.10 \%$, alkaloid $2.06 \%$ and cyanogenic glycoside $0.0062 \%$ while the saponin, flavoniod, alkaloid and cyanogenic glycoside for the wet leaves include $0.80 \%, 0.80 \%, 1.02$ and $0.005 \%$ respectively. This result shows that the presence of saponin, alkaloid and cyanogenic glycoside are higher in the dry leaves comparatively to the wet leaves, while flavonoid is higher in concentration in moringa oleifera flower than its leaves. . It has been shown from the analysis that the percentages of the phytochemicals are not lethal especially the cyanogenic glycoside in the sample which indicates less toxicity and a minor quantity of hydrogen cyanide which can easily be detoxified for better health benefits.
\end{abstract}

Keywords: Moringa, phytochemicals, Talinium triangulare, flavonoids, saponins.

DOI: $10.7176 / \mathrm{CMR} / 11-10-06$

Publication date: December $31^{\text {st }} 2019$

\section{Introduction}

The importance ofTalinum triangulare cannot be over-emphasized. It is a plant species that is very crucial medically, traditionally, industrially, economically and ornamentally. Hence, this research was intended to ascertain or analyse some phytochemicals in Talinum triangulare and their usefulness (Fugile, 2010). The phytochemicals analysed were found to be some of the parameters in plant Talinum triangulare which has made it very useful to man and his environment. Some of the phytochemicals determined were saponin, flavoniod, cyanogenic glycoside using the dry and fresh leaves a. It has been discovered from the analysis that the percentages of the phytochemicals are not lethal and so may not cause harm or death. This has also shown that some parts of Talinum triangulare are very edible and can be properly digested, also its usefulness for good health (Frank, 2006). Talinum triangulare is a plant that often exhibits a wide range of biological and pharmacological activities such as anti-inflammatory,antifungal and antibacterial properties (Nwoha et al, 2007). It also delays the on-set of diseases such as stroke and heart diseases (Jonathan, 2004). It belongs to the family, Portulacaceae. Talinum triangulare plant is found in west Africa, West Indies, South America (Adams, 1999) and in warmer parts of the world (Xu, 1996). Water leaf has catalase, flavonoid, tannins, saponins, alkaloids, and alpha and beta-trocopherds contents. Sridhar et al, (1993) in addition to crude protein. Water leaf crude protein content compares favourably with that of cowpea, peanut, millet and cashew nuts. (Zentner, 2011). It is cultivated to use as a vegetable (leaves, green pods, flower seeds), for spice (mainly roots) for cooking and cosmetic oil (seeds) and as a medicinal plant (all plant organs). Medicinally, Talinum triangulare parts are used for treatment of anaemia, anxiety, asthma, fever, semen deficiency (Frank, 2006). Nutritionally,Talinum triangulare have been used to combat malnutrition, especially among infants and nursing mothers. (Olson, 2010). The leaves can be eaten fresh, cooked, or stored as dried powder for many months without refrigeration and reportedly without loss of nutritional value. (Harold, 2004). Talinum triangjlare leaves contain more vitamin A than carrots, more calcium than milk, more iron than spinach, more vitamin $\mathrm{c}$ than milk, more potassium than bananas and that the protein quality the leaves rival that of milk and eggs. (Ted and Elevitch, 2010). The nutritional properties of Talinum triangulare are now well known that there seems to be little doubt of the substantial health benefit to be realized by consumption. It has high antioxidant properties making it a valuable source of vitamins A, C and E. it is one of the highest naturally occurring sources of anti-oxidants (Hossein, 2008). Talinum triangulare oil contains four times the collagen of carrot oil, this helps to rebuild skin's collagen fibres which minimizes wrinkling. (Hossein, 2008). The plant being very light with pleasant tasting is similar to olive oil in containing unsaturated fats, it is good for healthier eating. The plant is also called Philippine spinach. It can be eaten raw or cook like spinach. It is rich in vitamins, minerals and proteins. This plant is a healthy vegetable (Bolaji et al, 2008).Talinum triangulare contain an appreciable amount of flavonoids, alkaloids, saponins, among others and low level of toxicants like tannins, since it contains substantial amount of bioactive compounds. It can therefore be concluded that Talinum triangulare leaves can contribute significantly to the health management of man and should be recommended in our daily nutritional need. Bioactive compounds are non-nutrient plant components but have acclaimed health benefits. Flavonoids are polyphenol 
antioxidants found naturally in plants. Saponins have beneficial effects on blood cholesterol levels, cancer, bone health and stimulation of the immune system. In South America, the crushed plant is applied as a poultice on contusion inflammation and tumor. Decoctions are used for painful eyes and to aid recovery from blows and falls. Talinum triangulare has medical values especially in the fact that it contains phenol and flavoniod which is an anti-oxidation effect in animals (Enwere, 1998). It is known that oxygen free-radicals, the reactive oxygen species (ROS) are involved in cancer, diabetes, cardiovascular diseases, neurodegenerative diseases Agency (Afonso et $a l, 2007)$. It is believed that antioxidant of water leaf donate hydrogen atoms to free radical which convert the radical into no-toxic species and therefore inhibits the propagation phase of lipid oxidation (WOO, 2006). Polyphenols from plant vegetables have been found to exert their beneficial effects by removing free radicals, chelating metal catalyst, activating antioxidant enzymes (Atrooz et al, 2009). The antioxidant activity of any plant is mainly because of the phenolic and flavonoid content. Talinium triangulare has the antioxidant which helps it to quench tumor formation caused by free radicals. Talinium triangulare is used in traditional medicine as tonic and enhance the cognitive ability. Hydromethanol extract from the branch of water leaf is a source of allantom, aspartic acid and steroidal saponin mixture which inhibit Tripanossoma Crizi (Amorim et al, 2013) that causes disease. The aqueous leaf extract of Talinum triangulare (TT) has anti-ulcer properties (Ngozi et al, 2013).

(a)<smiles>O=c1cc(-c2ccccc2)oc2ccccc12</smiles><smiles>O=c1cc(-c2ccccc2)c2ccccc2o1</smiles><smiles>c1ccc(C2COc3ccccc3C2)cc1</smiles>

(b) Isoflavan structure

(c) Neoflavonoids structur<smiles>OCCOC(Oc1ccccc1CO)C(O)CO</smiles>

(d)

Figure 1: Phytochemicals Contents.

\section{2: MATERIALS AND METHOD}

Sample Collection and treatment. Fresh leaves of water leaf (Talinum triangulare) were bought from hawkers in a common market (Rumukwuta market) in Port Harcourt, Rivers State of Nigeria and were transported to the laboratory under suitable temperature.

\section{3: SAMPLE PREPARATION AND EXTRACTION}

The leaves were destalked, washed and some sun dried by constantly exposing the leaves to sunlight for 2 to 3 days and turning of the leaves to avert fungal growth. The leaves were later milled to obtain the vegetable leaf meals (VLMS) using mortar and pestle, some of the leaves were also ground fresh using mortar and pestle and both were stored in refrigerator in a well labeled air-tight containers for analysis. 


\section{4: PHYTOCHEMICAL ANALYSIS}

Quantitative analysis were carried out to determine the presence of some phytochemicals such as; saponins, flavonoids and glycoside in Talinum triangulare.

Determination of Flavonoid: (.Bohm and Kocipal-Abyazam, 1999).

$10 \mathrm{~g}$ of the sample was repeatedly extracted with $100 \mathrm{ml}$ of $80 \%$ aqueous methanol at room temperature. The solution was filtered. The filtrate was later transferred to a crucible and evaporated to dryness over a water bath and weighed to a constant weight.

Determination of Saponins: .(Forster and Hartonut,2006)

$10 \mathrm{~g}$ of sample was first defatted using acetone solvent by soxhlet continuous extraction method. The residue in the thimble was extracted with methanol solvent into a pre-weighed distillation flask by soxhlet continuous extraction. The extract was distilled to dryness and further placed in an air oven to eliminate all traces of methanol solvent. The flask was then reweighed to obtain the weight of the Saponin in the sample.

Determination of Cyanogenic Glycoside( Lindhorst T. K. 2007).

$10 \mathrm{~g}$ of sieved sample (sieve No. 20) in $800 \mathrm{ml} \mathrm{Kjeldahl} \mathrm{flask} \mathrm{was} \mathrm{added} 200 \mathrm{ml}$ water and allowed to stand for $3 \mathrm{hrs}$. Steam distillation was employed and $155 \mathrm{ml}$ was distillated into sodiumhydoxide solution $(0.5 \mathrm{~g}$ in $20 \mathrm{ml} \mathrm{H} 2 \mathrm{O})$ and diluted to $250 \mathrm{ml} .10 \mathrm{ml}$ of the distillate was titrated against $0.02 \mathrm{~N}$ silvernitrate using micro-burette. End-point was determined at permanent mixture turbidity

\section{5: RESULT AND DISCUSSION}

Table 1: NAMES OF THE PHYTOCHEMICAL DRY SAMPLE WET SAMPLE

FLAVONOIDS (\%) $\quad 1.60 \quad 0.80$

SAPONINS $\quad(\%) \quad 1.10-0.70$

GLYCOSIDE $\quad(\%) \quad 0.0062 \quad 0.005$

ALKALOID $\quad(\%) \quad 2.06 \quad 1.02$

Quantitative phytochemical data of dry and wet samples of Talinum triangulare

\section{References}

Adams CD (1999) Talinum triangulare Flowering plants of Jamaica. University of West Indies, Mona, Jamaica pp 268

Altrooz OM (2009). The antioxidant activitity and polyphenoic contents of different plant seeds extracts. Pakistan Journal of Biological Sciences, 12(15): 1063-1068.

Amorim CZ, Flores CA, Gomes BE, Marques AD, Cordeiro RS (2013) screening for antimalarial activity in genus Potomorphe. J Ethnopharmacol. 24(1): 101-106

Bolaji PT, komolafe GO and Alli E(2008) Drying characteristics of selected local vegetable. Nigerian food Journal, Vol. 26 no 1 pp.138-143

Brito-Arias A. (2007) Oxidative Effect of Cyanides Compounds in Plants and Animals. J. Chem. Edu. 20(09): 1567.

Egwim E, Hypolycemic potencies of crude ethanolic extracts of cashew roots and unripe pawpaw fruits in guinea pigs and rats. Journal of Herbal pharmacotherapy 1979, 5(1), 27-34.

Francis K, Becker, Goel, G and H.P.S Makkar (2007) phorbol esters: structure, biological activity and toxicity in animals. Int. .J. Toxico., 26:279-288

Fugile A and Olson ME(2010) Flora of North America Editorial Committee, ed. Moringaceae: Drumstick Family. New York and Oxford Pp. 167-169. 
Galeotti F, Barile E and Doki M. (2008) Flavonoid Effects on Plants Spp. J. Chem Edu 85(15):1586.Hartmut, Foerster (2009) "MetaCyc Pathway: saponin biosynthesis I"

Hong-Xiang, Xie Yong Ye and Yi-Ping (2009).” Advances in saponin-based adjuvants" Vaccine. 27 (12): 1787 1796.

Jonathan G. C.(2004), “Naturally Occurring Fish Poisons from Plants. J. Chem. Edu 81(10): 1457.

Lindhorst TK (2007) Analysis on Cyanides Compounds Effects on Plants. 24(6): 605-24.

Marston and Hostettmann, 1995. Saponins chemistry and pharmacology of natural products. University press Cambridge p. 3

Nwoha PU, Ojo GB, Ajayi SA, Ofusori DA,Oluwayinka OP, Odukoya SA and Falana BA(2007). Garcinia kola diet provides slight neuroprotection to mice hippocampal neurons against neurotoxin.J.Environ. Neurosci. Biomed. 1 (2): 125-136.

Richardo A. (1997) "Isolating Bioactive Compounds from Marine Organisms, Journal of Marine Biotechnology 5(4): 187-193.

Sridhar KR and Bhat R (1993), Lotus A potential nutraceutical source. J. Agric. Technol., 3: 143-155.

Woo H D (2013) "Dietary Flavonoid Intake and Smoking Related Cancer Risk: A Meta-Analysis, Plos ONE 8(9): e75604. Bibcode: 2013 Plos

Xu R, Zhao W, Xu J and Shao (1996) "Studies of Bioactive Saponins from Chinese Medicinal Plants". Advances in Experimental Medicine and Biology 404: 371-82, doi: 10.1007/978-1-4899-1367-8.

Zentner E (2011) "Effects of Phytogenic Feed Additives Containing quillaga Saponaria on Ammonia in Faltering Pigs. Journal of Phytochemicals in plant. 93(15):1265. 